\title{
Larotrectinib Sulfate
}

National Cancer Institute

\section{Source}

National Cancer Institute. Larotrectinib Sulfate. NCI Thesaurus. Code C156895.

The sulfate salt form of larotrectinib, an orally available, tropomyosin receptor kinase (Trk) inhibitor, with potential antineoplastic activity. Upon administration, larotrectinib binds to Trk, thereby preventing neurotrophin-Trk interaction and Trk activation, which results in both the induction of cellular apoptosis and the inhibition of cell growth in tumors that overexpress Trk. Trk, a receptor tyrosine kinase activated by neurotrophins, is mutated in a variety of cancer cell types and plays an important role in tumor cell growth and survival. 